EXEMPLARIa Classica

Journal of Classical Philology

23, 2019, 37-64 • ISSN 1699-3225

http://dx.doi.org/10.33776/ec.v23i0.3771

\title{
CRITICAL NOTES ON CATULLUS' EPIGRAMS (POEMS 74, 84, 95, 100, 115)
}

\author{
Marc Dominicy \\ Département de Langues et Lettres \\ Université libre de Bruxelles (ULB) \\ mdomini@ulb.ac.be
}

\begin{abstract}
SUMMARY
The following emendations are proposed: furorem for flere/solere (74.1); eius auunculus aiunt for liber auunculus eius (84.5); Zmyrna anus hinc ... (95.5); praestata ex animo est unica amicitia (100.6); Mentula, habes, with instar (115.1), altasque paludes (115.5), ipse es, maxime cultor (115.7).
\end{abstract}

KEY WORDS

Catullus - epigrams - textual criticism

\section{RESUMEN}

Se proponen las siguientes correcciones: furorem por flere/solere (74.1); eius auunculus aiunt por liber auunculus eius (84.5); Zmyrna anus hinc ... (95.5); praestata ex animo est unica amicitia (100.6); Mentula, habes, con instar (115.1), altasque paludes (115.5), ipse es, maxime cultor (115.7).

Palabras Clave

Catulo - epigramas - crítica textual

Fecha de recepción: 04/01/2019

Fecha de aceptación y versión definitiva: 23/05/2019 
In the following, I will propose new emendations for a set of passages in Catullus' epigrams. ${ }^{1}$ In each case, I will print the version I suggest adopting with a reduced apparatus that only records those manuscript readings, and those conjectures, that prove directly relevant to my hypothesis. ${ }^{2}$ The ensuing discussion will summarize the state of the question. I will also try to show that the correction suggested conforms to the constraints of meter and language, and (in some cases at least) sheds some light on the symbolic or intertextual dimension of the poem at hand. In addition, I will provide an account of the corruption process that presumably operated, with the aim of establishing the palaeographical verisimilitude of my proposal.

\section{VERSES 74.1-2}

Gellius audierat patruum obiurgare furorem, si quis delicias diceret aut faceret.

1 furorem scripsi: flere OGR: solere Parthenius, uulgo

All scholars adopt Parthenius's solere (see Kiss, CO), in spite of the fact that this correction produces semantic or contextual incoherence. Indeed, solere rules out the possibility that audierat might describe a specific auditory experience of Gellius' that would have made him able to perceive in one fell swoop his uncle's propensity to scold. It follows that Gellius should have learned about his uncle's habit by hearsay; see the following translations: "Gellius had heard that his uncle used to lecture anyone / who spoke of or indulged in sex" (Goold); "Gellius had heard that uncle liked to reprimand / Any who spoke or acted naughtily" (Lee); "Gellius avait entendu dire que son oncle ne cessait pas de gronder contre ceux qui parlaient de l'amour ou le faisaient" (Lafaye); "Gellio aveva sentito che lo zio s'arrabiava / ogni volta che si diceva o faceva qualcosa di divertente" (Chiarini). ${ }^{3}$ But this is

${ }^{1}$ I am grateful to the two anonymous referees at Exemplaria Classica for their many comments and suggestions for improving this article.

${ }^{2}$ For the sake of brevity, I will refer to the readings transmitted by recentiores by means of the usual cover letter $\varsigma$ and I will provide in my discussion the detailed information that can be found in the invaluable website Catullus Online, built up under the leadership of Dániel Kiss [henceforth "Kiss, CO"] (consulted on 22 May 2019).

${ }^{3}$ G.P. Goold, Catullus, London 1983, 193; [A.]G. Lee, The Poems of Catullus, Oxford 1990, 125; G. Lafaye, Catulle. Poésies, Paris 1923, 83; G. Chiarini, quoted by A.M. Morelli, "Catullo in versi italiani", in F. Condello \& B. Pieri (eds.), Note di traduttore. Sofocle, Euripide, Aristofane, Tucidide, Plauto, Catullo, Virgilio, Nonno, Bologna 2011, 63-89. It should be noticed that most of the Italian translations quoted by Morelli, 83-7, including his own ("Gellio aveva sempre sentito lo zio che fustigava / chi pensava o si dava alla bella vita"), are incorrect in that they implicitly make soleo modify audio, perhaps because all attested 
highly implausible: the patruus of an upper-class family in ancient Rome was supposed to play his proverbial role of a guardian of morality through direct contact with his nephew; moreover, the whole poem and other related epigrams $(88,89,90,91)$ dwell on the promiscuity of Gellius' family life. I thus suggest correcting flere to furorem ("Gellius had heard uncle reprove erotic madness / If anyone spoke or acted naughtily"). For examples where obiurgo takes a direct object that refers to a failing or vice, see $T h L L$ 9.2.71.85-72.13 and e.g. Cic. ad Q. fr.3.1.10 (de tribunatu quod scribis, ego uero nominatim petiui Curtio, et mihi ipse Caesar nominatim Curtio paratum esse rescripsit meamque in rogando uerecundiam obiurgauit); Sen. dial. 4.24.2 (nihil nisi quod in oculos incurret manifestumque erit credamus, et quotiens suspicio nostra uana apparuerit, obiurgemus credulitatem), epist. 100.10 (uolo luxuriam obiurgari, libidinem traduci, inpotentiam frangi); Quint. inst. 1.2.21 (proderit alicuius obiurgata desidia, proderit laudata industria). On the erotic use of furo( $r$ ) in Catullus, see 15.14, 50.11 (metaphorical), 64.54, 64.94, 64.124, 64.197, 64.405, 68.129. ${ }^{4}$ The contrast between the simple pleasures evoked by delicias and the reproval expressed by furorem (a buzz-word of conservative critics of immorality in the late Roman Republic) reflects the conflicting viewpoints of the lovers concerned and Gellius' uncle, whose contempt for sexuality goes far beyond what is expected from a traditional patruus; ${ }^{5}$ the sexual abuse Gellius submits him to thus appears as an inverted image of his excessive attitude. A palaeographical drift (plausibly due to the loss of the strokes indicating the nasal vowel and the first occurrence of $-r$ - $)^{6}$ led from furorem to fuore, hence fluore $>$ fluere $>$ flere. See flurorem for fluorem at Nemes. ecl. 3.68, furere/furore for fluere

collocations of audio and soleo apply to repeated auditory perceptions and not - obviously to the (unique) auditory perception of a recurring action or event ; see e.g. Caecil. com. 196 [Ribbeck] (audire ignoti quom imperant soleo, non auscultare); Cic. de orat. 1.129 (saepe enim soleo audire Roscium, cum ita dicat, se adhuc reperire discipulum, quem quidem probaret, potuisse neminem); Sal. Iug. 85.13 (quae illi audire aut legere solent, eorum partem uidi, alia egomet gessi; quae illi litteris, ea ego militando didici); Ov. met. 6.4523 (quales audire solemus / Naidas et Dryadas mediis incedere siluis); Sen. epist. 82.2 (audire solemus sic quorundam uitam laudari quibus inuidetur).

${ }^{4}$ More on this in R. Pichon, De sermone amatorio apud Latinos elegiarum scriptores, Paris 1902, 157-8; F. Bellandi, Lepos e Pathos. Studi su Catullo, Bologna 2007, 14-15, 49 n. 95, 232, 249-50; L. Bocciolini Palagi, "Amor e furor nell'Eneide. Accostamenti e convergenze", in P. Mantovanelli \& F. Romana Berno (eds.), Le parole della passione. Studi sul lessico poetico latino, Bologna 2011, 19-38; R. Moreno Soldevila, "Locura de amor", in Diccionario de motivos amatorios en la literatura latina (siglos III a.C.-II d.C.), Huelva 2011, 245-8.

${ }^{5}$ See P. Campana, Il ciclo di Gellio nel liber catulliano. Per una nuova lettura di Catull. 74, 80, 88, 89, 90, 91, 116, Pisa 2012, 22 n. 28: "[all'] immagine tradizionale del patruus obiurgator [...] si sovrappone in questo caso specifico quella del censore 'professionista'".

${ }^{6}$ See G. Friedrich, Catulli Veronensis Liber, Leipzig/Berlin 1908, 134, who mentions meos $(O)$ for meros (13.9), libente (OGR) for libenter (31.4), totaque (OGR) for tortaque (64.13). 
at Aetna 512,530. Owing to their semantic proximity, fletu alternates with fluctu at 66.63; fletus with fluctus at Lucr. 6.74, Ov. ars 2.139, Manil. 5.221, Maxim. eleg. 3.86; luctus, presumably from fluctus, with fletus at Sen. Ag. 924, Iuvenc. 3.14.

\section{VERSES 84.1-6}

Chommoda dicebat, si quando commoda uellet dicere, et hinsidias Arrius insidias, et tum mirifice sperabat se esse locutum, cum quantum poterat dixerat hinsidias. credo, sic mater, sic eius auunculus aiunt, sic maternus auus dixerat atque auia.

5 eius scripsi; fortasse heius: liber $O G R \mid$ aiunt scripsi: eius $\varsigma$ : eius est $O G R$

Butterfield has mounted a case against the vulgate reading eius (ms. 122, 1460) of v. 5 , on the motive that this genitive form is almost systematically avoided in dactylic verse before the third century A.D. - most exceptions to this regularity appearing in the didactic poetry of Lucretius (35 occurrences), Manilius (15 occurrences) and Germanicus (one occurrence); he suggests correcting eius to aeque, while Heyworth opts for olim and McKie for ante. ${ }^{7}$ In my view, these conjectures provide metrical fillers that do not really improve on eius; Butterfield's palaeographical hypothesis ("if the final letter of aeque were misread as a compendium for est [...], the remaining equ differs not too greatly from the ductus litterarum of eius") remains inconclusive in that the addition of est probably resulted from the interpretive problems raised by liber (see below): some scribe understood the second hemistich as meaning "his uncle is free". Instead of deleting the distich

7 D. Butterfield, "On the Avoidance of eius in Latin Poetry", RhM 151, 2008, 151-67, particularly at 152, 162-5; S.J. Heyworth, "Notes on the Text and Interpretation of Catullus", PCPhS n.s. 44, 1998, 85-109, at 106-7; D.S. McKie, Essays on the Interpretation of Roman Poetry, Cambridge 2009, 130-1. At Manil. 2.377, Butterfield, 166 n. 53 accepts Bentley's correction uisus eis for transmitted uis(us) eius (A.E. Housman, M. Manilii Astronomicon Liber Secundus, London 1912, 38). His comments and figures fail to mention Cic. Arat. 15.2 (atque eius ipse manet religatus corpore torto), Homer. 22 (dona simul praefert. uincuntur fletibus eius) and Sil. 11.85 (en ego progenies eius, qui sede Tonantis). At Cic. Arat. 15.2, the monosyllabic scansion of eius is a feature inherited from iambo-trochaic verse; see Plaut. Epid. 356 and Pacuv. trag. 36 [Ribbeck] (with eius); Ter. Haut. 284, Lucil. 905, Lucr. 1.149, Laber. mim. 98 [Ribbeck $=90.1$ Panayotakis] and Verg. catal. 9.35 (with cuius); Naev. com. 2 [Ribbeck] and Ter. Andr. 480 (with huius). Lucil. 279 (hanc ubi uult male habere, ulcisci pro scelere eius) illustrates a similarly archaic diction with bisyllabic eius. 
with Trappes-Lomax, ${ }^{8}$ I am inclined to maintain eius for the following reasons. In the first place, Butterfield suspects passages in other poets where, in my opinion, eius should not be emended away. Consider, for instance, its two attestations in Propertius: est etiam aurigae species Vertumnus et eius / traicit alterno qui leue pondus equo (4.2.35-6); Actius hinc traxit Phoebus monumenta, quod eius / una decem uicit missa sagitta rates (4.6.67-8). Butterfield dismisses the first distich as spurious and substitutes illi for eius in the second. Yet these passages share a characteristic feature, viz. the occurrence, at the end of the hexameter, of a grammatical (short) monosyllable (preposition or conjunction) followed by a bisyllabic word. This pattern occurs with a frequency of around 5\% in Propertius' first three Books, 7.6\% in Book 4, 25\% in Elegy 4.2 (vv. 7, 27, 35, 37, 39, 47, 55, 63) and $14 \%$ in Elegy 4.6 (vv. 25, 35, 37, 55, 59, 67). ${ }^{9}$ This should justify us in maintaining vv. 4.2.35-6, and thus eius in both cases. Second, Butterfield claims that Hor. sat. 2.1 .70 (scilicet uni aequos uirtuti atque eius amicis) and 2.6.76 (et quae sit natura boni summumque quid eius) belong to a "work [...] deliberately written in a style sermoni propiora $[. .$.$] so there is$ no need for anxious apology concerning either instance of the prosaic eius therein". I do not see why an analogous conclusion could not hold for an epigram that scoffs at people for distorting language, all the more so since auunculus is a low-register word; see Serv. ad Verg. Aen. 3.343 (quidam "auunculus" humiliter in heroico carmine dictum accipiunt), Courtney on Juv. 6.615, 14.43, and Bettini, who detects irony in Sil. 3.245-8 (sed dux in sese conuerterat ora Sychaeus, / Hasdrubalis proles, cui uano corda tumore / maternum implebat genus, et resonare superbo / Hannibal haud umquam cessabat auunculus ore). ${ }^{10}$ The formal similarity between Hor. sat. 2.6.76 and the two hexameters in Propertius can be explained by the fact that, in Elegy 4.2, Vertumnus' speech abounds in colloquialisms, and that Elegy 4.6 is a discursively ambiguous piece of work. ${ }^{11}$ Third, Butterfield too hastily assumes that eius "serves no meaningful function in the couplet", since the parallel with Silius suggests that auunculus eius (or eius auunculus; see below) may indirectly render the own words of Arrius, who will say auunculus meus (or meus auunculus). Fourth, the epigraphic writing heius (CIL 3.3917, 6.35765, 8.3520, 8.14281/25364;

8 J.M. Trappes-Lomax, "Seven Suggestions in Catullus", Mnemosyne 55, 2002, 73-82, at 78-9; Catullus: A Textual Reappraisal, Swansea 2007, 258-9.

9 See the figures for each Book in V. Viparelli Santangelo, L'esametro di Properzio. Rapporti con Callimaco, Naples 1986, 96-100; M. Dominicy, "Notes critiques sur l'élégie IV, 2 de Properce", Latomus 68, 2009, 923-32, at 932.

${ }^{10}$ E. Courtney, A Commentary on the Satires of Juvenal, London 1980, 343-4, 566; M. Bettini, The Ears of Hermes: Communication, Images, and Identity in the Classical World, translated by W.M. Short, Columbus 2011, 207-8.

${ }^{11}$ See, most recently, É. Coutelle, Properce. Élégies. Livre IV, Brussels 2015, 207-32. 
ThLL 7.2.456.77-8) shows that the pronoun was a natural candidate for the addition of a spurious aitch, and thus that Catullus could mock Arrius' pronunciation either by sticking to the correct variant or by suggesting that the word should be spelt with a $h$-; more on this below.

The reading liber does not make sense either as an epithet ("free-born", "freeman") or as a cognomen that would convey some allusion to Bacchus (as envisaged by Bell, Marshall and Baker, and Arkins).12 Lenchantin de Gubernatis, Dolç, Oksala and Heyworth favor libere, a conjecture (apparently due to Federico Carlo Wick; see Kiss, $C O$ ) that, contrary to what is claimed by Nisbet, proves quite satisfactory from a semantic point of view in that it may have "something of the force of quantum poterat" (so Heyworth). ${ }^{13}$ But, as rightly pointed out by Nisbet, the elision produced is most probably unmetrical. In the Catullan corpus, most elisions of cretic words involve a nasal vowel (a graphic - $m$ ); see 64.211, 64.359, 64.366, 66.27, 67.31, 68.3, 68.4, 68.90, 73.6, 90.2, 91.9. ${ }^{14}$ Except for 97.6 (ploxeni habet), which features a very rare lexeme (ThLL 10.1.2447.8-20), comparable examples with oral vowels expectedly involve words ending in $-\bar{o}$ (6.11 argutatio inambulatioque [phalaecian]; 85.2 sentio et; 91.2 perdito amore) or $-\bar{e}$ (45.3 perdite amo [phalaecian]; 104.3 perdite amarem).${ }^{15}$ Moreover, since argutatio, which occurs in a highly anomalous line, is strictly speaking not a cretic word, and sentio most probably had its last vowel shortened like nesciŏ in the same verse (nesciŏ, sed fieri sentiŏ et excrucior), the examples with an oral vowel are three variations of the same stereotypic formula; compare with Polliō amat at Verg. ecl. 3.84, 3.88.16

12 A.J. Bell, "Note on Catullus, 84", CR 29, 1915, 137-9; B.A. Marshall \& R.J. Baker, "The Aspirations of Q. Arrius”, Historia 24, 1975, 220-31; Baker \& Marshall, “ 'Avunculus liber' (Catullus 84.5)", Mnemosyne 30, 1977, 292-3; B. Arkins, "Textual Questions in Catullus", in C. Deroux (ed.), Studies in Latin Literature and Roman History 7, Brussels, 1994, 211-26, at 225 .

${ }^{13}$ M. Lenchantin de Gubernatis, Il libro di Catullo Veronese, Turin 1928, 243-4; M. Dolç, Q. Valerio Catulo. Poesías, Madrid 1963, 118; P. Oksala, Adnotationes criticae ad Catulli carmina, Helsinki 1965, 94-5; R.G.M. Nisbet, "Notes on the Text of Catullus", PCPhS n.s. 24, 1978, 92-115 [reprinted in Collected Papers on Latin Literature, S.J. Harrison (ed.), Oxford, 1995, 76-100], at 110; Heyworth, "Notes", 106-7.

${ }^{14}$ At 66.43, maximum in oris (Puccius) is a correction of transmitted maxima in oris, but there are good reasons for adopting a quite different text; see M. Dominicy, "Critical Notes on The Lock of Berenice (Callimachus 110 Pf., Catullus 66)", Paideia 78/3, 2018, 1563-87, at 1571-3.

${ }^{15}$ See J. Soubiran, L'élision dans la poésie latine, Paris 1966, 207-21; M. Dominicy, "Catulliana”, $C Q$ n.s. 65, 2015, 628-54, at 631.

${ }^{16}$ Notice that $\operatorname{amo}(r)$ and related words (like amicus or amarus) also favor "prosodic hiatus", that is the shortening of a long monosyllable before an iambic word or an iambically-

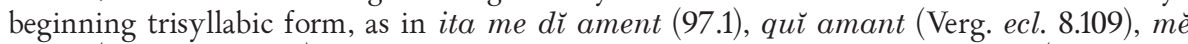
amas (Hor. sat. 1.9.38), nomen et arma locum seruant; tĕ, amice, nequiui (Verg. Aen. 6.507), at contra quăe amara atque aspera cumque uidentur (Lucr. 2.404); see Dominicy, "Catulliana", 643-4. 
The collocation liber auunculus does not conform to Hermann's bridge, which prohibits the occurrence of an unelided trochaic word or word-ending in the fourth foot of the hexameter; but here, as in the few other exceptions to this constraint in Catullus, the two words in contact belong to the same (noun or prepositional) phrase: nec tenuem texens sublimis aranea telam (68.49), Si qua recordanti benefacta priora uoluptas / est homini (76.12), Multas per gentes et multa per aequora uectus (101.1). ${ }^{17}$ This allows us to dismiss semper, proposed by Nisbet, adopted by Goold and favored by Thomson; dixit, dismissed by Nisbet but advocated by Butterfield and McKie; fatur (Watt). ${ }^{18}$ Bauer's gibber, already dismissed by Nisbet, is devoid of any contextual relevance. ${ }^{19}$ Heyworth's magnus fares better (see Cic. Brut. 222: M. Drusum tuum magnum auunculum), but this reference to Arrius' great-uncle (i.e. grandmother's brother) ruins the iconic contrast between v. 5 (Arrius' mother and her brother, thus one line further and one generation back) and v. 6 (Arrius' maternal grandparents, thus two lines further and two generations back); in addition, magnus does not account for the paradosis. ${ }^{20}$

I can think of two possible solutions to this crux.

The first one consists in correcting liber to asper. This epithet frequently applies to sounds, speech or speakers; see ThLL 2.0.810.33-82 and, in particular, Cic. Brut. 129 (C. Fimbria temporibus isdem fere sed longius aetate prouectus habitus est sane, ut ita dicam, luculentus patronus: asper maledicus, genere toto paulo feruidior atque commotior, diligentia tamen et uirtute animi atque uita bonus auctor in senatu), de orat. 3.216 (atque etiam illa sunt ab his delapsa plura genera leue, asperum, contractum, diffusum, continenti spiritu, intermisso, fractum, scissum flexo sono extenuatum, inflatum), 3.171 (conlocationis est componere et struere uerba sic ut neue asper eorum concursus neue hiulcus sit, sed quodam modo coagmentatus et leuis), fin. 4.28 .78 (quae rursus dum sibi euelli ex ordine nolunt [Stoici], horridiores euadunt, asperiores, duriores et oratione et moribus), nat. deor. 2.146 (auriumque item est admirabile quoddam artificiosumque iudicium, quo iudicatur et in uocis et in tibiarum neruorumque cantibus uarietas sonorum interualla distinctio, et uocis genera permulta, canorum fuscum, leue asperum, graue acutum, flexibile durum, quae hominum solum auribus iudicantur);

${ }_{17}$ D.O. Ross, Jr., Style and Tradition in Catullus, Cambridge, Mass. 1969, 129-30; G.O. Hutchinson, "The Catullan Corpus, Greek Epigram, and The Poetry of Objects", $C Q$ n.s. 53, 2003, 206-21, at 213 n. 27.

${ }_{18}$ Nisbet, "Notes", 110; Goold, Catullus, 200, 232; D.F.S. Thomson, Catullus, Toronto/ Buffalo/London 21998, 513; Butterfield, "On the Avoidance of eius", 162-3; McKie, Essays, 130 1; W.S. Watt, "Notes on Catullus", $Z P E$ 131, 2000, 65-8. 110 .

${ }^{19}$ J.B. Bauer, “†Liber avonculus. Catull. c. 84,5”, RhM 143, 2000, 222-3; Nisbet, "Notes”,

${ }^{20}$ Heyworth, "Notes”, 106-7. 
Ov. fast. 5.481-2 (aspera mutata est in lenem tempore longo / littera, quae toto nomine prima fuit [i.e. $r>l]$ ); Quint. inst. 11.3.15 (qualitas magis uaria. nam est et candida et fusca, et plena et exilis, et leuis et aspera, et contracta et fusa, et dura et flexibilis, et clara et obtusa), 11.3.63 (atrox [uox] in ira et aspera ac densa et respiratione crebra: neque enim potest esse longus spiritus, cum inmoderate effunditur). The strictly phonetic acceptation of asper referring to vowel aspiration appears later $(T h L L$ 2.0.810.40-4), but see the similar use of $a(d)$ spiratio and $a(d)$ spiro by Cic. orat. 160, Varro as quoted in Char. gramm. 73.17-18, 82.7 [Keil], Nigidius Figulus as quoted in Gell. 13.6.3, and Quint. inst. 1.4.14, 1.5.19-20, 1.6.21, 12.10.57. Though both asper and $a(d)$ spiratio / $a(d)$ spiro are of uncertain etymology, ${ }^{21}$ native speakers could not but associate them with each other. Owing to the trivial confusion between $p$ and $u$, hence $b$, the sequence sicasber $=$ siculber can have been interpreted as sicc liber. ${ }^{22}$

The second solution consists in printing eius auunculus aiunt. For a similar "metalinguistic" use of aio, see Cic. orat. 155: pro "deum" atque hominum fidem "deorum" aiunt. If this is the authentic version, one should assume that, owing to the similarity between eius and aiunt, a scribe wrote eius auunculus eius, that the first occurrence of the pronoun was subsequently replaced with the stopgap liberi, understood as the genitive of liber = "child" (for examples of this singular form, see ThLL 7.2.1303.791304.4), and that liberi finally shifted to liber.

Both corrections produce a sequence of three contiguous words each of which begins with a vowel. Such triplets are rather unfrequent in Catullus' dactylic lines (hexameters and pentameters); see Appendix 1, where similar sequences of four or more words ('wxyz...') are analyzed as sequences of two or more overlapping triplets ('wxy', 'xyz',...). Poems 62 and 64-116 contain 1,103 lines and 76 triplets (7\%); if sequences of overlapping triplets are counted as one attestation only, the ratio drops to $5 \%$ (56 lines). Poems 62 and 64-68 contain 916 lines and 35 triplets (4\%), while the ratio drops to $3 \%$ if sequences of overlapping triplets are counted as one attestation only $(25$ lines). By contrast, Poems 69-116 contain 187 lines, 41 triplets (22\%), with a ratio of $17 \%$ if sequences of overlapping triplets are counted as one attestation only (31 lines). Poems 71, 73, 83, 85, 93, and 94 show a high percentage of

${ }^{21}$ See A. Ernout \& A. Meillet, Dictionnaire étymologique de la langue latine. Histoire des mots, retirage de la $4{ }^{\mathrm{e}}$ édition augmentée d'additions et de corrections par J. André, Paris 2001, 51, 642-3.

${ }^{22}$ On the confusions between $p$ and $u, u$ and $b$, see e.g. Friedrich, Catulli Veronensis Liber, 206; L. Havet, Manuel de critique verbale appliquée aux textes latins, Paris 1911, 190.808-9, 218-9.928-30; V. Väänänen, Le latin vulgaire des inscriptions pompéiennes, Berlin 21959, 50-2, 54; M. Dominicy, "Propertius 3.1.27", Mnemosyne 62, 2009, 417-31, at 428; "Propertius, 4.5.19-21", $\operatorname{RhM} 153,2010,144-87$, at 163, 173; "Critical Notes on Catullus 61”, $\operatorname{RhM} 158,2015,138-66$, at 160. 
triplets $(50-100 \%)$, with a ratio of $17-50 \%$ if sequences of overlapping triplets are counted as one attestation only (1 line among 6 in 73 and 83; 2 lines among 6 in 71; 1 line among 2 in 85, 93 and 94). In Poem 107, the transmitted text contains 3 different lines (vv. 1, 2 and 5) with one triplet (38\%); in the revised text I have proposed, ${ }^{23}$ optantique optigit umquam (v. 1) is corrected to optatum cuiquam optigit umquam and †optandus † uita to optandam esse unam, so that the ratio remains unchanged. As for Poem 84 with one of the corrections I envisage at v. 5 , it contains 5 triplets (42\%), with a ratio of $33 \%$ if sequences of overlapping triplets are counted as one attestation only (4 lines among 12). 72 triplets (respectively, 53 lines) out of 76 (respectively 56) exhibit at least one feature that contributes to mitigating the perception of each of their vocalic beginnings, viz. (i) "Left (prod)elision" between the first word of the triplet and the preceding word (e.g. 84.11 postquam illius Arrius isset; 25 triplets = 33\%); (ii) "Internal (prod)elision(s)" (e.g. 99.8 abstersisti omnibus articulis; 44 triplets $=58 \%$ ); (iii) One or more word(s) of the triplet is/are monosyllabic, either lexically or prosodically, owing to (prod)elision (e.g. 65.8 obterit ex oculis, 86.6 omnibus una omnes; 62 triplets $=82 \%) ; 24$ (iv) One or more word(s) of the triplet is a / are $h$-word(s), i.e. begin(s) with an aspirated vowel (e.g. 64.194 huc huc aduentate; 29 triplets $=38 \%$ ). Two of the four exceptions occur in Poem 84 with one of the corrections I envisage at v. 5. One of the two occurrences of insidias (v. 2) should be pronounced (and therefore spelt) with initial aspiration, which eliminates this exception; like Calphurnius (1481; see Kiss, CO) and Trappes-Lomax, I think that the first occurrence should play that role..$^{25}$

All in all, I am inclined to prefer eius auunculus aiunt for the following reasons. In the first place, one may wonder why Arrius' maternal uncle should be distinguished from Arrius' mother and grandparents by such an unflattering and redundant epithet as asper. Second, the successive use of present aiunt and past perfect dixerat enhances the iconic contrast between v. 5 and v. 6 (see above). Notice that credo is compatible with firm knowledge and vivid experience (see e.g. Lutat. epigr. 1.1, v. 8 of Poem 2, and Verg. Aen. 4.12), and that, while dixerat (v. 4) combined with the imperfects of vv. 1-4 possesses its "aspectual" value of close temporal proximity, and "current relevance", to the state of affairs described in the main clauses, the same form expresses temporal remoteness and the lack of "current relevance" in v. 6; compare with 10.28 (istud quod modo dixeram me habere), where the past perfect expresses the lack of "current relevance" in spite of the temporal proximity marked by modo (what the speaker just said is not to be taken

23 "Catulliana", 650-1.

${ }^{24}$ Monosyllabic words (especially grammatical ones) belong to the same prosodic group as the preceding and/or following word; most monosyllables listed in Appendix 1 are grammatical.

25 Trappes-Lomax, Catullus, 258-9. 
into account anymore). ${ }^{26}$ Third, in the text obtained the second hemistich of v. 5 is particularly rich in phonological parallelisms: /ĕjjŭ-ăjjŭ/, /ă-ă/, 5 occurrences of $/ \breve{\mathrm{u}} /$. Fourth, the coupling of eius and aiunt within a triplet of words that begin with a vowel may be indicative of the fact that this exceptional sequence could be made regular by the addition of a spurious aitch to one of these two bisyllables; eius would be the natural candidate for that (see above). I thus tentatively print eius with "fortasse heius" in the apparatus.

\section{VERSES 95.5-8}

Zmyrna anus hinc Satrachi penitus mittetur ad undas, Zmyrnam cana diu saecula peruoluent, at Volusi annales Paduam morientur ad ipsam et laxas scombris saepe dabunt tunicas.

5 anus hinc scripsi: canas OGR: cauas Puteolanus

Vv. 5-6 raise intricate problems owing to the extraordinary complexity of the conceptual network that grounds their various referential and symbolic interpretations. The main topic is the difference between the future receptions of Cinna's and Volus(i)us' poems (see Appendix 2, which focuses on Cinna's Zmyrna for the sake of simplicity). At this first level, we have to take into account three "ordinary" metaphors ${ }^{27}$ that map a source-domain into a target-domain (in short: $\mathrm{SD} \Rightarrow \mathrm{TD}$ ): (i) "The future reception of an artistic work (TD) is like human life (SD), though perhaps incredibly long or even eternal" (Poems have a life of their own, This poem will live forever, etc.); (ii) "Human life (TD) is like the motion of a physical body in time (SD)" and (iii) this motion (TD) is like the motion of a physical body in space (SD)" (Life is a journey through time, Life is a path and death a

${ }^{26}$ On the notion of "current relevance", used in linguistic descriptions of the English present/past perfect, see e.g. F.R. Palmer, A Linguistic Study of the English Verb, London 1965, 72-7; I. Depraetere, "On the Resultative Character of Present Perfect Sentences", Journal of Pragmatics 29, 1998, 597-613.

${ }^{27}$ On those "ordinary" metaphors that prove indispensable to our mind for conceptualizing the world we belong to, see G. Lakoff \& M. Johnson, Metaphors We Live By, Chicago/ London 1980, Philosophy in the Flesh: The Embodied Mind and Its Challenge to Western Thought, New York 1999; Lakoff \& M. TURner, More Than Cool Reason: A Field Guide to Poetic Metaphor, Chicago/London 1989. The source- and target-domains of a metaphor can be conceived of as analogous to Richards's "vehicle" and "tenor"; see I.A. Richards, The Philosophy of Rhetoric, New York/London 1936, 96, 119. For a general introduction to cognitive approaches to metaphor, see B. Dancygier \& E. Sweetser, Figurative Language, Cambridge 2014. 
destination, etc.). ${ }^{28}$ The "Motion in Space $\Rightarrow$ Motion in Time" mapping is a generalization of "the ego-moving metaphor, wherein the observer's context progresses along the time-line towards the future". ${ }^{29}$ In Catullus' text, this metaphorical triplet combines with two additional mappings, viz. (iv) "Human life (TD) is like a story (SD)" (I do not want to tell the story of my life, This is a new chapter in my life, etc.) and (v) "The end of human life (TD), which does not necessarily reduce to physical death, is like the arrival at a river bank (SD)" (Yes, we'll gather at the river, Take us to the river, etc., not to mention the infernal rivers Styx and Acheron). At a second level, two metonymic associations (Literary work $\leftrightarrow$ Character, Literary work $\leftrightarrow$ Material support, in particular book-roll), illustrated by such "ordinary" discourse sequences as Though a very well written book, I really did not feel any sympathy at all for Madame Bovary or "Madame Bovary" is on the top shelf. That is a great novel, ${ }^{30}$ license both a literal reading and a new mapping. In the literal reading, Zmyrna (the character of Cinna's poem), in the course of her human life which takes place $(\rightarrow)$ during a certain time interval, moves $(\rightarrow)$ in space until arriving $(\rightarrow)$ at the bank of Satrachus. According to the new mapping (vi) (SD $\Rightarrow$ TD), "A story (TD) unfolds like a book-roll (SD)"; hence, by transitivity, "Human life (TD) unfolds like a bookroll (SD)". Finally, the epithet cana (v. 6) produces an effect of "trespass" in that, instead of qualifying a human being (Zmyrna in the literal reading) at a certain stage of her/his life (target-domain of the "ordinary" metaphor), it applies to chronological intervals belonging to time conceived of as moving relative to a stationary observer. ${ }^{31}$ In other words, the "trespass" activates $(\uparrow)$

${ }^{28}$ See Lakoff \& Turner, More Than Cool reason, 3-10.

${ }^{29}$ See Lakoff \& Johnson, Metaphors, 41-5, Philosophy in the Flesh, 139-48; D. Gentner, M. Imai \& L. Boroditsky, "As Time Goes By: Evidence for two systems in processing space $\rightarrow$ time metaphors", Language and Cognitive Processes 17, 2002, 537-65 (quoted here).

30 On metonymy, see Lakoff \& Johnson, Metaphors, 35-40; Lakoff \& Turner, More Than Cool Reason, 100-6; G. Fauconnier, Mental Spaces: Aspects of Meaning Construction in Natural Language, Cambridge 1994; Dancygier \& Sweetser, Figurative Language.

${ }^{31}$ See R.O.A.M (alias Oliver) Lyne, Words and the Poet: Characteristic Techniques of Style in Vergil's Aeneid, Oxford 1989, 73-4, 98-9, 118-9, 126, 134-5 who, relying on the pioneering work of M.S. Silk, Interaction in Poetic Imagery, with special reference to early Greek poetry, Cambridge 1974, viii, 24-25, 138-49, defines this kind of "trespass" as the "intrusion" of "tenor" (i.e. target-domain) language into the "vehicle" (i.e. source-domain) of the basic metaphor or simile. Lyne insightfully points out that "trespass" may convey literal meaning (here, the allusion to Zmyrna's old age in the future); see also Silk, 242-3. Notice that, in "ordinary" speech, time intervals that become "old" belong to the past (English good old times, French le bon vieux temps, Spanish los viejos dias de oro, etc.), and not to the future, as is the case here. Cognitive theorists would analyze "trespass" as an effect of conceptual "blending"; see M. Turner, The Literary Mind, Oxford/New York 1996; G. Fauconnier, Mappings in Thought and Language, Cambridge 1997; Fauconnier \& Turner, The Way We Think: Conceptual Blending and the Mind's Hidden Capacities, New York 2002; Dancygier \& Sweetser, Figurative Language; M. Dominicy, "Metaphor, Metonymy, and Personification in the Language of Robotics", in J.-P. Laumond, E. Danblon \& C. Pieters (eds.), Wording Robotics: Discourses and Representations 
the "Motion in Space $\Rightarrow$ Motion of Time" mapping which is a generalization of "the time-moving metaphor, wherein time is conceived of as a river or conveyor belt on which events are moving from the future to the past", and proves therefore hardly compatible, in everyday speech, with the "Motion in Space $\Rightarrow$ Motion in Time" mapping. ${ }^{32}$ Since the story recounted by Cinna takes place in Cyprus, and Satrachus is a Cypriot river, Zmyrna's arrival at its bank amounts to a homecoming to her native place, and thus goes hand in hand with a metaphorical representation of the happy ending of the poem's "life". By contrast, Volus(i)us' Annales will finish its unhappy "life" at the bank of the Padua river and, by virtue of the mappings between space and time, the modest length of its journey, compared with Zmyrna/Zmyrna's (metaphorical/literal) travel to Cyprus, corresponds to its quick falling into oblivion, compared with Zmyrna's permanence in memory.

Though the reading canas in v. 5 obviously results from a "vertical" mistake, ${ }^{33}$ the humanistic correction cauas (v. 5; see Kiss, CO) should be dismissed. In all comparable attestations (see ThLL 3.0.716.39-48), cauus belongs to a noun phrase that refers either to deep river beds or deep (possibly engulfing) waters frequently enclosed by rocks and cliffs, or to deep-water channels; in addition, the surrounding context tends to describe or evoke negative and even sinister realities: see 17.4 (ne supinus eat cauaque in palude recumbat); Verg. georg. 1.117, 1.324-6 (ruit arduus aether, / et pluuia ingenti sata laeta boumque labores / diluit; implentur fossae et caua flumina crescunt), 2.186-8, 4.427-8, Aen. 3.566-7 (ter scopuli clamorem inter caua saxa dedere, / ter spumam elisam et rorantia uidimus astra); Aetna 488-92; Ov. am. 3.6.45-6, ars 3.94, met. 6.370-81, 13.892, 14.791-2, Ib. 224-6 (qua caua de Stygiis fluxerat unda uadis, I pectoraque unxerunt Erebeae felle colubrae / terque cruentatas increpuere manus); Lucan. 1.396, 1.406, 2.422, 4.455-8 (impendent caua saxa mari, ruituraque semper / stat (mirum!) moles et siluis aequor inumbrat. / huc fractas aquilone rates summersaque pontus / corpora saepe tulit caecisque abscondit in antris), 10.248; Stat. Theb. 4.478, 4.699-701, 8.272, 9.347-8 (horruit unda nefas, siluae fleuistis utraeque, / et grauiora cauae sonuerunt murmura ripae), 9.449-53, 9.502-3; Sil. 10.205-7, 12.135-42.

on Robotics, Cham (Switzerland) 2019, 33-57.

${ }^{32}$ See Lakoff \& Johnson, Philosophy in the Flesh, 139-48; Lakoff \& Turner, More Than Cool Reason, 44-6; Gentner, Imai \& Boroditsky, “As Time Goes By” (quoted here); Catullus' lines show that poetic discourse can combine the two mappings. Perhaps the most famous illustration of that phenomenon occurs in Lamartine's Le Lac: Il [le temps] coule, et nous passons! ("Time flows, and we pass!"). For a systematic analysis of time metaphors in poetry, see most recently A. Piata, The Poetics of Time - Metaphors and Blends in Language and Literature, Amsterdam/Philadelphia 2018.

${ }^{33}$ Havet, Manuel, 151-3.568-73. 
None of the corrections proposed sofar seems convincing. The "metapoetic" epithet sacras (Heyworth) remains poorly motivated in the context at hand. Against the choice of a descriptive epithet like uagas (Trappes-Lomax) or citas $\left(\mathrm{M}^{\mathrm{c}} \mathrm{Kie}\right)$, one can argue that "the actual appearance of the Cypriot Satrachos is irrelevant, since neither Catullus nor his readers can have known a thing about it" (so Nisbet); ${ }^{34}$ notice that, contrary to what is claimed by Trappes-Lomax, uagas does not receive any justification from Harrison's emendation of uaga to caua at 61.110 (also adopted by $\mathrm{M}^{\mathrm{c}} \mathrm{Kie}$ ) since the paradosis should be maintained there.$^{35}$ Nisbet's suas produces acceptable sense by alluding to Zmyrna's homecoming to her native place (see above); but, in my view, this redundant modifier gives too much prominence to the literal reading of v. 5 .

I suggest editing Zmyrna anus hinc ... For the metrical template of the line thus corrected, see Prop. 2.18.20 (ipsa anus haud longa curua futura die); Ov. fast. 2.571 (ecce anus in mediis residens annosa puellis); Mart. 10.8.2 (nolo: anus est. uellem, si magis esset anus). As an epithet of both Zmyrna (literal predication) and Zmyrna (metaphorical predication), anus anticipates the "trespass" of v. 6 (cana $[. .$.$] saecula) and echoes two other$ attestations of its "metapoetic" use, viz. 68.45-6 (sed dicam uobis, uos porro dicite multis / milibus et facite haec carta loquatur anus) and 78b.3-4 (nam te omnia saecla / noscent et, qui sis, fama loquetur anus). In v. 3, milia recalls milibus of 68.46; in v. 5, saecula recalls saecla of $78 \mathrm{~b} .3$ while fama of $78 \mathrm{~b} .4$ also occurs in passages that, like v. 6 with peruoluent, derive from Enn. var. 18 [Vahlen] = Cic. Tusc. 1.34 (uolito uiuos per ora uirum): succedet fama uiuusque per ora feretur (Verg. Aen. 12.235), uenies tu quoque in ora uirum / Caesaris et famae uestigia iuncta tenebis (Prop. 3.9.32-3), ore legar populi, perque omnia saecula fama, / siquid habent ueri uatum praesagia, uiuam (Ov. met. 15.878-9, with omnia saecula). ${ }^{36}$ For the collocation hinc [...] penitus, see Verg. ecl. 1.64-6 (at nos hinc alii sitientes ibimus Afros, / pars Scythiam et rapidum cretae ueniemus Oaxen / et penitus toto diuisos orbe Britannos), which partly derives from Poem 11; Manil. 4.615-6 (hinc penitus iuuenisque fretum mersaeque puellae / truditur inuitum). Under the influence of cana, anus shifted to prosodically incorrect cănas and hinc was dropped; see famuloque t-/ canus for fama loquetur anus (78b.4), with loquetur written loquet plus a neglected diacritic. ${ }^{37}$

${ }^{34}$ Nisbet, "Notes", 111; Heyworth, personal communication to G.P. Goold [1990], reported by J.D. Morgan, “The Waters of the Satrachus (Catullus 95.5)”, CQ n.s. 41, 1991, 252-3; TrappesLomax, Catullus, 269-71; McKie, Essays, 242-4 n. 113.

35 Trappes-Lomax, Catullus, 147, 271; S.J. Harrison, “Catullus 61.109-13 (again)”, PCPhS n.s. 31, 1985, 11-12; M'Kie, Essays, 243 n. 113; Dominicy, "Critical Notes on Catullus 61", 164-5.

${ }^{36}$ See Dominicy, "Catulliana", 648.

${ }^{37}$ W.M. Lindsay, Notae Latinae: An Account of Abbreviation in Latin Mss. of the 


\title{
4. VERSES 100.5-7
}

\author{
cui faueam potius? Caeli, tibi: nam tua nobis \\ praestata ex animo est unica amicitia, \\ cum uesana meas torreret flamma medullas.
}

6 praestata scripsi: perfecta OGR: perspecta $\varsigma \mid$ ex animo est scripsi: est igitur est $O$ : est exigitur est $G$ : est igitur est $R$, al. exigitur est $R^{2}$

Any convincing emendation of v. 6 should account for the strange readings of the manuscript tradition. One can surmise that the archetype transmitted est/ex igitur est ${ }^{38}$ - which immediately rules out exigit hoc (Coluccio Salutati; see Kiss, $\mathrm{CO}$ ). The second est is all the more surprising since lengthening in hemistich-final igitür would have made the line acceptable to a mediaeval scribe. Lachmann's exhibita est belongs to later usage (ThLL 5.2.1424.1-15); Wiman's ingenita est does not fit in with the occasional content of the poem. Both exilio/auxilio est (Maehly, Tucker) and eximie/ egregie est (Koch, Baehrens) are open to palaeographical objections; see Friedrich's desperate attempt to derive the paradosis from Baehrens's text. ${ }^{39}$ One attractive solution consists in restituting igni "tried by fire" (see Cic. epist. $=$ fam. 9.16.2, off. 2.38, . red. in sen. 23 ; ThLL 7.1.293.16-19), which elegantly anticipates v. 7. Schoell's ex igni est (in fact, ex ignest), probably an adaptation of Froehlich's inappropriate est signis, is printed by Mynors with "sed ex uix recte" in the apparatus. Trappes-Lomax's igni perspecta est fails to account for the paradosis; Palmer's est igni tum fares better in this respect (Goold, Thomson, Syndikus), ${ }^{40}$ but tum definitely looks like a palaeographical and metrical filler whose elision at the beginning of the

\footnotetext{
Early Minuscule Period (c. 700-850), Cambridge 1915, 372-5.

${ }^{38}$ For the confusions between est and $e(x)$, see Dominicy, "Catulliana", 640 n. 59.

${ }^{39}$ K. Lachmann, Q. Catulli Veronensis Liber, Berlin 1829, 74; G. Wiman, "Ad Catulli textum critica”, Eranos 62, 1963, 29-37, at 36; J. Maehly, "Zu Catullus", Neue Jahrbücher für Philologie und Pädagogik 103, 1871, 341-57, at 356; T.G. Tucker, "Catullus: Notes and Conjectures", CQ 4, 1910, 1-10, at 8; H.A. Koch, "Coniectanea in poetas Latinos", in Symbola philologorum Bonnensium in honorem Friderici Ritschelii collecta. Fasciculus prior, Leipzig 1864, 312-58, at 320; E. Baehrens, Catulli Veronensis Liber, Leipzig 1876-85, 1.107, 2.587-8; Friedrich, Catulli Veronensis Liber, 530.

${ }^{40}$ F. Schoell, "Zu Catullus”, Neue Jahrbücher für Philologie und Pädagogik 121, 1880, 471-96, at 485; J. von Gott Froehlich, review of Lachmann's 1829 edition, Abhandlungen der I. Classe der königlichen Akademie der Wissenschaften in München 5, 1849, 233-75, at 272; R.A.B. Mynors, Catulli Veronensis carmina, Oxford 1958, 100; Trappes-Lomax, Catullus, 278 [not recorded in Kiss, CO]; A. Palmer, review of R. Ellis, Catulli Veronensis Liber, Oxford ${ }^{2} 1878$, Hermathena 3, 1879, 293-363, at 361; G.P. Goold, “A New Text of Catullus”, Phoenix 12, 1958, 93-116, at 110, Catullus, 210, 232; Thomson, Catullus, 188; H.P. Syndikus, Catull. Eine Interpretation. Dritter Teil. Die Epigramme (69-116), Darmstadt 1987, 105.
} 
second hemistich remains suspect. ${ }^{41}$ Palmer's alternative solution (igni tum est) does not really improve on his first conjecture. ${ }^{42}$ Gaertner's ignibus est is unidiomatic. ${ }^{43}$

Recent scholars universally accept the participial form perspecta (ms.129a, 1450), surely preferable to perfecta or Lachmann's unidiomatic per facta. ${ }^{44}$ Yet I think it should be abandoned, given the two possible solutions I can envisage for this crux.

The first one consists in editing perpessa est animos, with ethicalpossessive nobis in v. 5. Catullus has perpetitur at 68.6. For animos meaning "ill temper(s)", see ThLL 2.0.98.70-99.18 and e.g. Plaut. Truc. 603; Cic. leg. agr. 2.96; Bibac. carm. frg. 14 [Courtney]; Verg. Aen. 1.57, 1.153, 11.366; Ov. ars 2.477, epist. 3.85, hal. 43-5, met. 6.688, trist. 5.8 .3 (quae tibi res animos

${ }^{41}$ See M. Zicàri, Scritti catulliani, P. Parroni (ed.), Urbino 1978, 265. Goold, "A New Text”, 110, Thomson, Catullus, 536 and Trappes-Lomax, Catullus, 278 mention 76.10 (quare cur tete iam amplius excrucies?), 88.10 (non si demisso se ipse uoret capite) and 102.4 (Corneli, et factum me esse puta Harpocraten) as possible parallels. At 88.10 and 102.4, the elided prepositive monosyllable and the following trochaic word ending in ĕ belong to the same (personal or infinitival) verb phrase. At 76.10, OGR transmit quare cur te iam amplius... Spondaic tete, which goes back to Baehrens (Catulli Veronensis Liber, 2.550 dubitanter), is metrically suspect, in that it should be analyzed as a reduplication similar to meme or sese, rather than the trochaic accusative of tute, with enclitic -těe. Among the 20 (possible) occurrences of tete anterior to the $7^{\text {th }}$ century (Lucil. 781 and Acc. trag. 369, 372 are dubious) I found in the "Musisque Deoque" and "Brepols CDS" databases (both consulted on 22 may 2019), 15 involve an elision (as happens at 101.5: quandoquidem fortuna mihi tete abstulit ipsum). In addition, the five exceptions cannot support the spondaic scansion. If, at Plaut. Capt. 577, one should print quid ais, furcifer? tun tete gnatum memoras liberum? $\left(\right.$ sept $\left.^{\mathrm{tr}}=\mathrm{tr}^{\mathrm{s}}\right)$, trochaic tete is metrical; at Plaut. Epid. 97 (qui lubidost male loqui? quia tu/tute tete deseris; $2 \times\left(\operatorname{tr}^{4}{ }^{\wedge}\right)$ or sept $^{\mathrm{tr}}=\operatorname{tr}^{{ }^{\wedge}}$ ), both text and meter are dubious, but if tete is authentic, its trochaic scansion is again metrical; see W.M. Lindsay, T. Macci Plauti Comoediae. Tomus I, Oxford 1904, ad locc., C. Questa, La metrica di Plauto e di Terenzio, Urbino 2007, 416-7. It follows that spondaic tete only occurs at Hyg. fab. 221.6 = Carm. de sept. 6 = Anth. 882.6 ("nosce" inquit "tete" Chilon Lacedaemone cretus), Ps.-Sedul. epigr. 3 (ut, tibi quae placeant, tete faciente, requirens), and Sylloge cod. Elnonensis 1.12-13 (integer, humanus, largus, districtus eodem / tete more gerens). Prisc. gramm. 2.592.4-7, 596.10-12 [Keil] confirms that the reduplicative analysis of tete is a feature of Late and Mediaeval Latin. I thus prefer Housman's (in J. P. Postgate, Gai Valeri Catulli Carmina, London 1889, viii) quare cur iam tete amplius excrucies? Among the 18 Catullan elisions between the two hemistichs of the pentameter, 6 involve enclitic -que $(68.56,68.82,73.6$, $91.10,95.2,99.12)$; the elided vowel is also an ě in three other cases $(75.4,71.6,104.4)$.

${ }^{42}$ Palmer, Catulli Veronensis Liber, London 1896, lii. Catullus has 15 (prod)elisions where the second word in contact is a - lexically or prosodically (owing to elision) - monosyllabic word occurring at the caesura of the pentameter; in 14 cases, the preceding word is polysyllabic: 68.22/94 (tota est), 68.46 (facite haec), 68.82/73.6 (una/unum atque, with atque elided; see n. 41), 68.154 (solita est), 76.14 (uerum hoc), 76.16 (siue id), 76.18 (ipse in), 84.8 (eadem haec), 86.4 (magno est), 87.4 (tuo ex), 89.4 (quare is), 91.2 (nostro hoc); in the only exception, 76.26 (o dei, reddite mi hoc pro pietate mea), the two postpositive monosyllables in contact belong to the same verb phrase.

${ }^{43}$ T. Gaertner, "Kritisch-exegetische Überlegungen zu Catullgedichten”, AAntHung 47, 2007, 1-41, at 36-7.

${ }^{44}$ See Gaisser, Catullus, 405; Lachmann, Q. Catulli Veronensis Liber, 74. 
in me facit, improbe?); Epiced. Drusi 375-6; Manil. 4.12-13. For perpeti taking a direct object that refers to a behavior or attitude and its (pseudo-) verbal expression, see Plaut. Men.719,742-3 (non ego istaec flagitia possum perpeti / ... / quaeso hercle, mulier, si scis, monstra quod bibam / tuam qui possim perpeti petulantiam); Ter. Eun. 47-8 (an potius ita me comparem / non perpeti meretricum contumelias?); Cic. har. resp. 42, Mur. 19; Colum. 10.11-12 (nam neque sicca placet, nec quae stagnata palude / perpetitur querulae semper conuicia ranae); Mart. 12.82.13-14 (omnia laudabit, mirabitur omnia, donec / perpessus dicas taedia mille "Veni!"); Tac. ann. 3.15.2, dial. 20.1. For the metaphor that constantly links passionate states to fire and burning, see e.g. Ter. Haut. 366-7 (haec arte tractabat uirum, / ut illius animum cupidum inopia incenderet); Verg. Aen. 4.54 (his dictis impenso animum flammauit amore); Ov. epist. 4.1516 (adsit, et, ut nostras auido fouet igne medullas, / figat sic animos in mea uota tuos!); Octavia 792 (hinc urit animos pertinax nimium fauor).

The second solution reads praestata ex animo est. Such past participle forms of praesto remain highly unfrequent before Late Latin - praestatum (M. Iunius Brutus, quoted by Prisc. gramm. 474.22-3 [Keil]; Plin. nat. 25.25.4), praestata (AE 2000.344.14b.38; December 18, 148) - but their use was perhaps favored, in everyday speech, by the analogy with the future participle praestaturus (see e.g. Cic. Att. 14.16.4, fam. 1.8.4, 6.8.1, 12.16.2; M. Iunius Brutus in Cic. ad Brut. 1.11.1, 1.13.1; Plancus in Cic. fam. 10.11.2; Decimus Brutus in Cic. fam. 11.9.1). For this use of praesto, "show, exhibit, manifest", with a direct object referring to a positive feeling or attitude towards someone else, see ThLL 10.2.914.50-915.16 and, in particular, Cic. Att. 11.1.1 (quam [perspectissimam beneuolentiam] si his temporibus miseris et extremis praestiteris,...); fam. 5.9.1 (peto a te, ut tuam consuetudinem et liberalitatem in me absente defendendo mihi praestes), 14.3.2 (pudet enim me uxori meae optimae, suauissimis liberis uirtutem et diligentiam non praestitisse); Oppius and Balbus in Cic. Att. $9.7 \mathrm{~b} .3$ (nam non mediocriter laboro ut utrique, ut uis, tuam beneuolentiam praestare possis quam mehercule te praestaturum confido); Scrib. Larg. praef. 3.2 (non praestat quam pollicetur hominibus misericordiam); Sen. dial. 3.14 .3 (quanto humanius mitem et patrium animum praestare peccantibus [...]!), 11.5.2 (ille enim indulgentiam tibi tamquam fratri praestitit, uenerationem tamquam parenti, cultum tamquam superiori); Ps. Quint. Decl. 9.9 (sustineas, adiuues, praestes affectum); in poetry: Hor. sat. 1.1.867 (miraris, cum tu argento post omnia ponas, / si nemo praestet, quem non merearis, amorem?); Ov. fast. 6.57-8 (nec tamen hunc nobis tantummodo praestat honorem / Roma: suburbani dant mihi munus idem). For passive forms of praesto, see e.g. Liv. Andr. trag. 16; Publil. sent. E.2; Liv. 43.18.11; Val. Max. 4.7.0 (sincerae uero fidei amici praecipue in aduersis rebus cognoscuntur, in quibus quidquid praestatur totum a 
constanti beniuolentia proficiscitur), 5.4 .3 (commendabilis est pietas, quae mansuetis parentibus praestatur); Mart. 2.34.3; Juv. 16.49; Plin. paneg. 88.3 (tanto magis digni sunt, quibus honor omnis praestetur a nobis, quia non est necesse). For ex animo meaning "from the bottom of one"s heart", see 109.3-4 (di magni, facite ut uere promittere possit, I atque id sincere dicat et ex animo) and e.g. Ter. Ad. 72, 919, Eun. 175, 179, Haut. 958; Lucr. 3.194; Cic. nat. deor. 2.168, Phil. 11.34, Pis. 81; Hor. ars 432; Ov. ars 3.472 .

If we opt for perpessa, the corruption process involved the confusion between capital $P$ and $F,{ }^{45}$ and a mistake on two minims $(s s / c t)$; see e.g. the alternation between passis, fusis and fossis at Ov. met. 8.107, fessa/passa for fassa at Stat. Theb. 8.654, pastas for pactas at Anth. 21.183, perfici for perpeti at Cic. dom. 98 (ThLL 9.1.1627.13-15). If we opt for praestata, it involved the common confusions between forms of praesto and persto (see e.g. Ov. fast. 1.49; Nux 128; Manil. 3.293; Sil. 3.380; Iuvenc. 3.376; Maxim. eleg. 3.15) and between st and $f(l),{ }^{46}$ plus another mistake on two minims $(a / e c)$. In both cases, animos (mis-segmented as anim os) or anim(o) est accounts for the paradosis: anim was normalized as enim and subsequently replaced with its mediaeval Latin synonym igitur (I found 19 occurrences of pleonastic enim igitur in the "Brepols CDS" database [consulted on 22 May 2019]).

All in all, I prefer praestata ex animo est for three reasons. In the first place, though os may have given rise to es(t), animo est is more plausible from a palaeographical viewpoint. Second, ex animo is a Catullan phrase (see above). Third, in other examples in Catullus of an ethical-possessive dative, the alternative construction with a possessive modifier is ruled out by meter: conserues puerum mihi pudice (15.5, with pyrrhic mihi); puella nam mi, quae meo sinu fugit, / amata tantum quantum amabitur nulla (37.11-12, with monosyllabic mi; compare with 87.1-2: Nulla potest mulier tantum se dicere amatam / uere, quantum a me Lesbia amata mea est); "nouistis", sic ipse flagitabam, / "Camerium mihi, pessimae puellae?" (55.9-10, with pyrrhic mihi); non tamen ante mihi languescent lumina morte $(64.188$, with iambic mihi $) .{ }^{47}$ By contrast, the dative of beneficiary is regular with praesto (see above).

${ }^{45}$ W.M. Lindsay, An Introduction to Latin Textual Emendation Based on the Text of Plautus, London 1896, 85; Havet, Manuel, 160.608.

${ }^{46}$ See madescent for madefient at 64.368, ferris $f(r)$ ingere for ferri stringere at 66.50; desiflore $(m)$ for desistere at 75.4 (mentioned by M'Kie, Essays, 53-4 n. 182, who suggests correcting perflantem to praestantem at Lucan. 9.349); Prop. 2.7.2 (stemus for flemus); Paneg. in Mess. 87 (stabilis for facilis); Ov. trist. 4.10.86 (fructos for structos); Sen. Phaedr. 372 (stringi for fingi), Herc. f. 285 (fetisti(s) and fecisti for stetisti); [Sen.] Herc. O. 1739 (stare for fleri); Housman, Classical Papers, 1.154.

${ }^{47}$ On 37.11 and 55.10, see Dominicy, "Catulliana", 644-5. 


\section{PoEm 115}

Mentula, habes instar triginta iugera prati, quadraginta arui: cetera sunt maria.

cur non diuitiis Croesum superare potis sit, uno qui in saltu tot bona possideat, prata, arua, ingentes siluas altasque paludes usque ad Hyperboreos et mare ad Oceanum?

omnia magna haec sunt, tamen ipse es, maxime cultor, non homo, sed uero mentula magna minax.

1 habes $\mathrm{s}$ : habet $O G R|| 5$ altasque paludes : saltusque paludesque OGR || 7 ipse es $(\mathrm{t}) \mathrm{s}$ : ipse si $O G R \mid$ maxime scripsi: maximus $O G R$ | cultor Rossberg: ultor OGR

Substantival instar governing a genitive frequently occurs as the attribute of a copula sentence that may contain a dative referring to the possessor, beneficiary or evaluator; ${ }^{48}$ some examples: Cic. Brut. 191 (Plato enim mihi unus instar est centum milium), Pis. 52 (unus ille dies mihi quidem immortalitatis instar fuit, quo in patriam redii); Ov. epist. 15.141-2 (antra uident oculi scabro pendentia topho, / quae mihi Mygdonii marmoris instar erant), met. 13.851-2 (unum est in media lumen mihi fronte, sed instar / ingentis clipei),14.124(numinis instar eris semper mihi); Epiced. Drusi 471 (est tibi, sitque precor, multorum filius instar); Val. Max 8.15.1 (unique illi instar atrii Capitolium est); Sen. epist. 61.1 (id ago, ut mihi instar totius uitae dies sit). The well-known alternation between mihi est and habeo thus produces constructions where the expression consisting of instar and its genitive is the predicative attribute of the direct object of habeo; see e.g. Ov. am. 3.6 .93 (fontis habes instar pluuiamque niuesque solutas), ars 1.675-6 (quaecumque est Veneris subita uiolata rapina, I gaudet et improbitas muneris instar habet), met.12.266-7 (telique habet instar, in alta / quae fuerant pinu, uotiui cornua cerui), Pont. 2.3.42 (instar et hanc uitam mortis habere puta); Vell.1.8.6 (hic centum homines electos appellatosque patres instar habuit consilii publici); Curt. 4.14.22 (matrem meam, duas filias, Ochum, in spem huius imperii genitum, principes, illam sobolem regiae stirpis, duces uestros reorum instar uinctos habet); Priap. 40.4 (hoc pathicae summi numinis instar habent). It follows that Catullan scholars have gone astray when supposing that, in v. 1, instar should modify the numerals triginta and quadraginta, or the measure expressions triginta iugera and quadraginta (iugera). The only

${ }^{48}$ See ThLL 7.1.1968.41-1974.24 and H. Nettleship, Contributions to Latin Lexicography, Oxford 1889, 487-9. 
example that may seem to support this hypothesis (Cic. Att. 16.5.5: mearum epistularum nulla est ouvaywyń, sed habet Tiro instar septuaginta ${ }^{49}$ contains a variant of the common construction where instar combines with a genitive noun phrase that includes a numeral (see, for instance, Liv. 26.28.11: duarum instar legionum); its apparent singularity stems from the fact that septuaginta does not vary for case (see Varro rust. 1.1.10: de Magonis dempsit instar librorum VIII; Vell. 2.20.4: triginta legionum instar) and that the contextually accessible head noun (epistularum) is left implicit. The right literal translation of vv. 1-2 will thus sound as follows: "Mentula owns, serving as pasture, thirty iugera; forty serving as plowland”. The syntactic discontinuity is compensated by the location of instar at the penthemimeral caesura and of the genitives in line- or hemistich-final position; compare with Ov. am. 3.6.93 and met. 12.266-7 (genitive in line-initial position, instar at the penthemimeral caesura) or Pont. 2.3.42 (instar and its genitive in line- and hemistich-initial position). Given the overall tone of the poem, the collocation of mentula and instar word-playingly refers to a phallus in erection; see Ps. Verg. Priap. 2.18 (stat mentula); Mart. 2.45.1 (quae tibi non stabat praecisa est mentula, Glypte), 3.73.2, 3.75.1-8 (Stare, Luperce, tibi iam pridem mentula desit / ...), 6.23.1-3 (Stare iubes semper nostrum tibi, Lesbia, penem: / crede mihi, non est mentula quod digitus. / tu licet et manibus blandis et uocibus instes), 6.49.2, 7.58.4, 11.25.2 (stare Lino desit mentula); 11.27.1 (Ferreus es, si stare potest tibi mentula, Flacce); Priap. 10.9, 73.2 (non stat in inguinibus mentula tenta meis), 80.1 (dubious).

While there is no reason to suspect instar, we cannot maintain unmetrical habet. Recent editors and commentators tend to dismiss Mentula, habes (nescio quis teste ms. 119, 1530; Lachmann) on the ground that "the change of person would be unacceptable" (Trappes-Lomax). ${ }^{50}$ But this easy correction

${ }^{49}$ R. Ellis, A Commentary on Catullus, Oxford ${ }^{21889,} 498$ and C.J. Fordyce, Catullus: A Commentary. Oxford ${ }^{21973,401-2}$ also mention Colum. 4.8.2 (recedere ab ipso codice instar unius digitis spatio conueniet) and 12.28.1 (item odorata trita, id est irim cribratam, quae sit instar pondo quincuncem et trientem, faeni Graeci pondo quincuncem et trientem, schoeni pondo quincuncem, in unum permisceto). Fordyce assumes that, in the first passage, "the genitive depends on spatio, 'a distance something like one finger's breadth', but his own translation conflicts with this claim; as happens elsewhere, the genitive depends on instar that in turn depends on spatio (spatio [quod sit] instar unius digitis, "a distance that should be equal to one finger's breadth"). As for 12.28.1, it is undoubtedly corrupt: the main verb permisceto takes as its direct objects odorata trita ..., irim cribratam ..., faeni Graeci pondo quincuncem et trientem and schoeni pondo quincuncem; as usual, instar is the attribute of the copula clause, but it cannot combine with accusative quincuncem et trientem; since quincuncem $(\varsigma)$ is a correction of the archetypal reading quinque/V(S. Hedberg, L. Iuni Moderati Columellae opera quae exstant. Rei rusticae Liber XII, Uppsala 1968, 43), one should edit quincuncis et trientis, as already proposed by [F.]K.L. Schneider, Formenlehre der lateinischen Sprache, Vol. 1, Berlin 1819, 456-7.

${ }^{50}$ Lachmann, Q. Catulli Veronensis Liber, 77; Trappes-Lomax, Catullus, 297. 
gains plausibility from an examination of v. 7. None of the emendations put forth for this problematic line proves satisfactory: ultro (Puteolanus 1473; see Kiss, $\mathrm{CO}$ ) gives feeble sense; maximu' multo (Brunér, advocated by TrappesLomax) requires an unacceptable ecthlipsis. ${ }^{51}$ I thus suggest editing ipse es, maxime cultor, / non ... (ipse est mss. 46 and 122, 1460; ipse es ms. 106, ca. 1495?, Puccius, nescio quis teste ms. 119, 1530; maximu' cultor Rossberg).52 Catullus reduces land-owning Mamurra to his plowshare, itself assimilated to his phallus by virtue of the metaphor that equates sexual penetration with plowing, ${ }^{53}$ so that maxime cultor simultaneously means "almighty/great cultivator" and "enormous/great fucker". Both cultor (see 61.2: o Heliconii / cultor; 64.300 ) and the vocative epithet maxime (see, for instance, Enn. Ann. 456 [Vahlen]; Verg. georg. 2.159, 2.170, Aen. 8.469, 8.572: maxime rector, 11.97 ) belong to elevated language ${ }^{54}$ compare with 34.5-6 (o Latonia, maximi / magna progenies Iouis) and 68.138 (Iuno, maxima caelicolum). This creates a funny contrast with the obscenity of the poem's conclusion, all the more so since vv. 7-8 parody Ennius (Ann. 621 [Vahlen]): machina multa minax minitatur maxima muris. ${ }^{55}$ The shift from ipse es to ipse $s i$ is palaeographically trivial; the mis-segmentation maximec ultor was normalized as maximus ultor, perhaps under the influence of Verg. Aen. 8.201, where the phrase refers to Hercules; see also transmitted nunc uisa (from the mis-segmentation nonc ulta) for non culta at Lucan. 9.945.

The fact that epigrams 94, 105 and 114 refer to Mentula in third-person discourse does not raise any difficulty. Gellius, another favorite scapegoat of Catullus, is variably addressed in second-person discourse $(80,91,116)$ or referred to in third-person discourse $(74,89,90)$; moreover, poem 88 combines the vocative Gelli with a hyperbolic third-person description of his sexual misbehavior. In addition, epigram 87 shows a comparable alternation between third- and second-person discourse respectively referring and addressed to Lesbia (nulla potest mulier tantum se dicere amatam / uere, quantum

${ }^{51}$ E. a. Brunér, "De ordine et temporibus carminum Catulli", Acta Societatis Scientiarum Fennicae 7, 1863, 599-657, at 642 n.; Trappes-Lomax, Catullus, 298. For a criticism of Trappes-Lomax's systematic recourse to ecthlipsis, see McKie, Essays, 157-9. At 116.8, dabi' supplicium is a parody of Enn. Ann. 100 [Vahlen] (hoc nec tu: nam mi calido dabi'sanguine poenas).

52 K. Rossberg, "Conjecturen zu Catullus", Neue Jahrbücher für Philologie und Pädagogik 115, 1877, 841-5, at 845 .

${ }^{53}$ J.N. Adams, The Latin Sexual Vocabulary, London 1982, 24-5, 82-6, 151-5. See also Dominicy, “De Catulle 113 à Properce IV, 11, 65-66”, Latomus 71, 2012, 392-403, where I argue for colebant at 113.1; I realize now that this correction was already proposed by R. Peiper, $Q$. Valerius Catullus. Beiträge zur Kritik seiner Gedichte, Breslau 1875, 61.

${ }^{4}$ H.P. Syndikus, Catull. Eine Interpretation. Zweiter Teil. Die grossen Gedichte (6168), Darmstadt 1990, 16 n. 3.

${ }^{55}$ See O. Skutsch, The Annals of Q. Ennius, Oxford 1985, 746-7; Syndikus, Catull. Eine Interpretation. Dritter Teil, 141-2; Thomson, Catullus, 552-3. 
a me Lesbia amata mea est. I nulla fides ullo fuit umquam in foedere tanta / quanta in amore tuo ex parte reperta mea est). There we should resist, I think, the temptation to adopt Scaliger's es in v. 2;5 indeed, the first distich clearly echoes 37.11-2 (puella nam mi, quae meo sinu fugit, / amata tantum quantum amabitur nulla), Scaliger's correction "involves an awkwardly complicated order of words" (Fordyce), and an equally brutal shift from third to second person occurs at Prop. 3.2.17-18 (fortunata meo si qua est celebrata libello! / carmina erunt formae tot monumenta tuae). ${ }^{57}$ As happens here, in Propertius' elegy 3.8 the third-person discourse that praises violence as an erotic quality in women (vv. 11-20) is embedded between a preceding and following second-person discourse addressed to the speaker's violent girl (vv. 1-10, 21-40).

Leo Spitzer's famous study on "dampening” (German Dämpfung) in Racine's tragedies can help us characterizing the poetic and rhetorical effects triggered by such plays on grammatical persons. ${ }^{58}$ Consider two examples of Spitzer's, taken from Andromaque: [Andromache to Pyrrhus] Captive, toujours triste, importune à moi-même, / Pouvez-vous souhaiter qu'Andromaque vous aime? (vv. 301-2); [Hermione to Orestes] J'ai voulu vous donner les moyens de me plaire, / Rendre Oreste content; mais enfin je vois bien / Qu'il veut toujours se plaindre, et ne mériter rien. / Partez, etc. (vv. 1234-7). ${ }^{59}$ In the first passage, Andromache dissociates the role she

56 J. Scaliger, Catulli, Tibulli, Properti nova editio, Paris 1577, 66; Castigationes in Catullum, Tibullum, Propertium, Paris 1577, 91; Fordyce, Catullus, 380. In order to maintain est (v. 2), Baehrens, "Vier Verbesserungen zu Catullus", Neue Jahrbücher für Philologie und Pädagogik 117, 1878, 769-70 and Trappes-Lomax, Catullus, 261 replace tuo (v. 4) with illo. But the sequence amore illo ex is metrically suspect: in the two comparable examples (me unum atque at 73.6, iam ipse in at 76.18), the three words in contact are (lexically or prosodically) monosyllabic; see n. 42 and Appendix 1. For Goold, Catullus, 261, "[t]he lack of point, together with the abrupt shift of Lesbia from third to second person, proclaims this to be a fragment not ready for publication". By contrast, Lee, The Poems of Catullus, 179, 183 claims that, in Poem 87, "[t] he change in the second couplet from third to second person is emotionally effective" and that, in Poem 109, "[t]he change from second to third person [...] is the reverse of that in LXXXVII"; Lee's argument proves all the more convincing since the two epigrams make use of the same lexicon.

${ }^{77}$ S.J. Heyworth, Cynthia: A Companion to the Text of Propertius, Oxford 2007, 289 prints es but this humanistic correction raises serious problems. We should rule out adverbial $q u \bar{a}$, which does not licence (prod)elision (see Soubiran, L'élision, 405, 411 and M. Dominicy, "L'élégie III, 22 de Properce. Propositions pour une nouvelle édition critique", AC 79, 2010, 13762, at 148-54). But pronominal quă produces semantic irrelevance and unacceptable syntax: see Heyworth's translation ("Happy you who are celebrated in my book, if any woman is", 566), which implies that si quă should be equivalent to si quă est, in spite of the fact that quă never occurs at the end of a prosodic group. At Hor. carm. 3.14.19, where quă is unmetrical, editors waver between $q u \bar{a}$ and quae.

${ }^{58}$ L. Spitzer, "Die klassische Dämpfung in Racines Stil", in Romanische Stil- und Literaturstudien I., Marburg, 1931, 135-268.

59 Spitzer, "Die klassische Dämpfung”, 136-8, 153-5. Literal translations: “Always a sad 
plays as a participant (speaker) in the dialogue from her role as a protagonist of the dramatic action; in the second excerpt, Hermione dissociates Orestesparticipant (addressee) from Orestes-protagonist. The distance thus created between the characters and their deeds or attitudes, while "dampening" the feelings and affects expressed or alluded to, paradoxically contributes to underlining the intensity of the emotive experience in question. This probably stems from the fact that the shift to third-person discourse allows the hearer/reader to "view" that experience under a dialogically generic "aspect": even if Andromache were not the speaker of vv. 301-2, Pyrrhus' wish would remain unfulfillable; even if Orestes were not the addressee of vv. 1234-7, the impossibility of finding him ways of pleasing Hermione, and of making him content, would subsist. Racine thus manages to provide both assertions with a form of "sublimity". By virtue of the principle that any mechanism of elevated language and speech can be resorted to in parody, both Catullus, in Poems 88 and 115, and Propertius, in Elegy 3.8, endow the reality described with an ironic "sublimity".

The pattern of Poem 115, with the two addresses at Mamurra enclosing the four-verse hy perbolic question, explains the modest size of the lands evoked ${ }^{60}$ - the construction with instar indicating that they are poor substitutes for real pasture or plowland - and the presence of maria. According to TrappesLomax, "nobody knows what maria is supposed to mean"; but this term receives a threefold motivation: commonsensical, given that seas are inapt for cultivation; referential, by alluding to the extension of villas and fish-farms into the sea; symbolic, since the metaphor that assimilates sailing to plowing transforms the mentula into a ship, and Mamurra into a daring navigator (see v. 6). ${ }^{61}$ In v. 5, the humanistic correction altasque paludes (ms. 31, 1457) should be preferred: a deep marsh such as the palus or uorago of poem 17 is the exact opposite of a place appropriate to country life and work, so that the very state of Mamurra's rural possessions reflects the devastation of his finances, already alluded to in poems 29, 41, 43 and 114; see Verg. georg. 4.48-9 (altae neu crede paludi, / aut ubi odor caeni grauis), Stat. Theb. 9.390-1 (quae te alta et ineluctabilis imo / condidit amne palus ...?).

captive, irksome to myself, / Can you wish Andromache to love you?"; "I have tried to find you ways of pleasing me, / And making Orestes content; but finally I see / That in fact he always wants to complain, and to be worth nothing. / Go...".

${ }^{60}$ W. Kroll, C. Valerius Catullus, Leipzig/Berlin 21929, 287; Syndikus, Catull. Eine Interpretation. Dritter Teil, 136-40; D. Konstan, "The Contemporary Political Context", in M.B. Skinner (ed.), A Companion to Catullus, Malden, Mass./Oxford, 2007, 72-91, at 75.

${ }^{61}$ Trappes-Lomax, Catullus, 297; R.G.M. Nisbet \& M. Hubbard, A Commentary on Horace: Odes, Book II, Oxford 1978, 302-4, on Hor. carm. 2.18.20-2; A. Marzano, Harvesting the Sea: The Exploitation of Marine Resources in the Roman Mediterranean, Oxford 2013; W. Görler, "Rowing Strokes: Tentative Considerations on 'Shifting' Objects in Virgil and Elsewhere", in J.N. Adams \& R.G. Mayer (eds.), Aspects of the Language of Latin Poetry, Oxford 1999, 269-86. 
Catullus has a similar use of altus at 63.1, 64.360, 66.68, 68.117 and 64.2889 (radicibus altas / fagos) where, pace Trappes-Lomax and McKie, the manuscript reading radicitus should be replaced with Lenz's radicibus: the trees in question have deep-going roots. ${ }^{62}$ In addition, altas points to the ancient etymology of the word saltus that designates Mamurra's estate at 114.1, 114.6 and 115.4; saltusque results both from a dittography and a "vertical" mistake (see above, on 95.5). ${ }^{63}$

62 Trappes-Lomax, Catullus, 198; McKie, Essays, 82-4; C.G. Lenz, C. Valerii Catulli Carmen de Nuptiis Pelei et Thetidis cum Versione Germanica Christiani Friderici Eisenschmidt ... illustravit C.G.L., Altenburg 1787, 168-9. See Nisbet, "Notes", 111, and for the inverse mistake, Havet, Manuel, 239.1009, on Verg. Aen. 5.449. McKie, 83 rightly points out that "[b]eeches are not found naturally by rivers, but prefer higher, well-drained (and where possible chalky) soils. In terms of the five types of tree Penios brings from the lush valley of Tempe, these are the odd one out". But, as argued by G. Williams, Tradition and Originality in Roman Poetry, Oxford 1968, 318-9, Catullus probably uses fagus with the meaning of Gk. 甲ๆyós 'oak-tree'.

${ }^{63}$ R. Maltby, A Lexicon of Ancient Latin Etymologies, Leeds 1991, 541; A. Michalopoulos, Ancient Etymologies in Ovid's Metamorphoses: A Commented Lexicon, Leeds 2001, 153; Goold, “A New Text”, 103. 

ApPendix 1: SEqueNCES OF THREE CONTIGUOUS WORDS, EACH OF WHICH (PHONOLOGICALLY) BEgINS WITH A VOWEL, IN CATULLUS' DACTYLIC VERSES. ${ }^{1}$

a) "regular" cases:

Left Internal Monosyllable(s) $h$-word(s)

62.5 Hymen o Hymenaee

(prod)elision (prod)elision(s)

62.5 o Hymenaee Hymen

62.5 Hymenaee Hymen ades

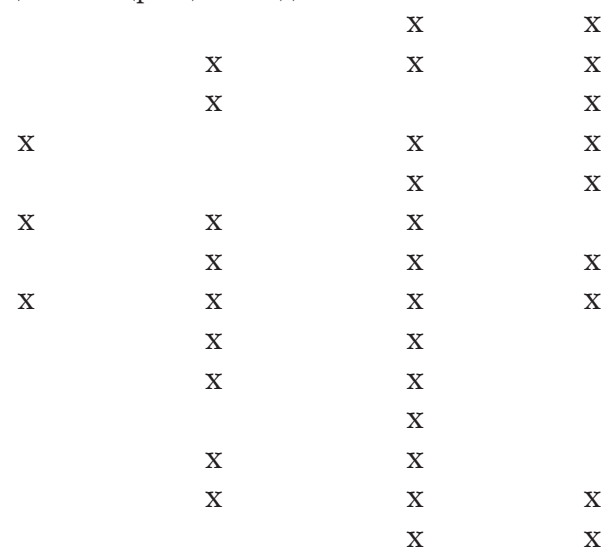

62.5 Hymen ades o $\quad \mathrm{x}$

62.5 ades o Hymenaee

62.54 eadem est ulmo

64.16 illa atque haud*

64.16 atque haud alia*

64.44 auro atque argento

64.93 atque imis exarsit

64.122 aut ut eam

64.127 unde aciem in

64.130 atque haec extremis

64.195 huc huc aduentate

64.232 ulla oblitteret aetas

64.242 anxia in assiduos

64.242 in assiduos absumens

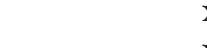

64.372 agite optatos animi

$\mathrm{x}$

$\mathrm{x} \quad \mathrm{x}$

$\mathrm{x} \quad \mathrm{x}$

64.396 armatas hominum est

$\mathrm{x}$

$\mathrm{x}$

65.8 obterit ex oculis

66.35 is haud in

66.60 ex Ariadneis aurea

66.86 ego ab indignis

68.36 huc una ex

68.62 exustos aestus hiulcat

$\mathrm{x}$

$\mathrm{x}$

$\mathrm{X}$

68.62 aestus hiulcat agros

68.82 una atque altera

68.86 isset ad Iliacos

x $\quad$ x

$\begin{array}{ll}x & x \\ x & x\end{array}$

$\mathrm{x}$

$\mathrm{x}$

$\mathrm{x}$

$\mathrm{x} \quad \mathrm{x}$

$\mathrm{x}$

$\mathrm{x}$

$\mathrm{X}$

$\mathrm{X}$

68.108 aestus in abruptum

68.146 ipsius ex ipso

68.152 haec atque illa

$\begin{array}{cc} & \mathrm{x} \\ & \mathrm{x} \\ & \mathrm{x} \\ \mathrm{x} & \mathrm{x}\end{array}$

$x$

$\mathrm{X}$

$\mathrm{X}$

${ }^{1}$ Passages where the text is doubtful are marked with an asterisk; see Kiss, $C O$ for the details, particularly on 64.16. In three cases (97.2, where OGR transmit utrum os an; 102.3, where some editors prefer me aeque esse inuenies illorum; 107.5, where insperanti should perhaps be corrected to insperatam), the alternative version does not modify the figures obtained in a significant way. In 99.8, one may prefer abstersti omnibus (which is irrelevant here) or abstersti mollibus (which eliminates the line). At 96.4 (atque olim missas), TrappesLomax, Catullus, 273-4 adopts the humanistic correction amissas. On 76.11, where I print quin tu animo offirmas teque istinc ipse reducis instead of transmitted quin tu animo offirmas atque istinc teque reducis, and 114.6, see my "Catulliana", 644 n. 82. On 84.2, 84.5, 100.6, 107.1 and 107.8, see above. 
68.152 atque alia atque

68.152 alia atque alia

$\mathrm{x}$

$\mathrm{x}$

71.1 alarum obstitit hircus

$\mathrm{x}$

71.6 illam affligit odore

71.6 affligit odore ipse

72.5 etsi impensius uror

73.6 unum atque unicum

73.6 atque unicum amicum $\mathrm{x}$

73.6 unicum amicum habuit $\mathrm{x}$

76.6 ex hoc ingrato

76.15 haec est hoc

76.15 est hoc est

76.22 expulit ex omni

80.8 ilia et emulso

83.6 irata est hoc

83.6 est hoc est

$\mathrm{x}$

83.6 hoc est uritur

83.6 est uritur et

84.2 et insidias Arrius $\quad \mathrm{x}$

84.8 audibant eadem haec $\mathrm{x}$

84.11 illuc Arrius isset x

85.1 odi et amo

86.2 est haec ego

86.6 omnibus una omnes $\mathrm{x}$

93.2 albus an ater

93.2 an ater homo

94.2 ipsa olera olla

97.2 utrumne os $a n^{*}$

99.8 abstersisti omnibus articulis*

100.6 ex animo est ${ }^{*} \quad \mathrm{x}$

102.3 esse inuenies illorum* ${ }^{*} \quad \mathrm{x}$

103.4 esse atque idem $\mathrm{x}$

107.1 optantique optigit umquam* ${ }^{*} \mathrm{x}$

107.2 insperanti hoc est

107.5 atque insperanti ipsa ${ }^{*} \quad \mathrm{x}$

107.8 optandam esse unam*

109.4 et ex animo

110.5 ingenuae est aut $\mathrm{x}$

114.6 ope ipse egeat* $\mathrm{x}$

115.6 usque ad Hyperboreos

115.6 ad Hyperboreos et $\mathrm{x}$

$\mathrm{x}$

$\mathrm{X}$

$\mathrm{X}$

$\mathrm{X}$

$\mathrm{X}$

$\mathrm{x} \quad \mathrm{x}$

$\mathrm{x} \quad \mathrm{x}$

$\mathrm{X} \quad \mathrm{X}$

$\mathrm{X}$

$\mathrm{x}$

$\mathrm{X}$

$\mathrm{X}$

$\mathrm{X}$

$\mathrm{X}$

$\mathrm{X}$

$\mathrm{X}$

$\mathrm{X}$

$\mathrm{X}$

$\mathrm{X}$

$\mathrm{X}$

X

$\mathrm{X}$

X

$\mathrm{X}$

$\mathrm{x}$

$\mathrm{X}$

$\mathrm{X}$

$\mathrm{X}$

$\mathrm{X}$

$\mathrm{x} \quad \mathrm{x}$

$\mathrm{x}$

$\mathrm{X}$

b) Exceptions:

62.32 aequales abstulit unam

64.197 inops ardens amenti

84.2 insidias Arrius insidias

84.5 eius auunculus aiunt* 
Appendix 2: The FigURATIVE NETWORK OF Vv. 95.5-8

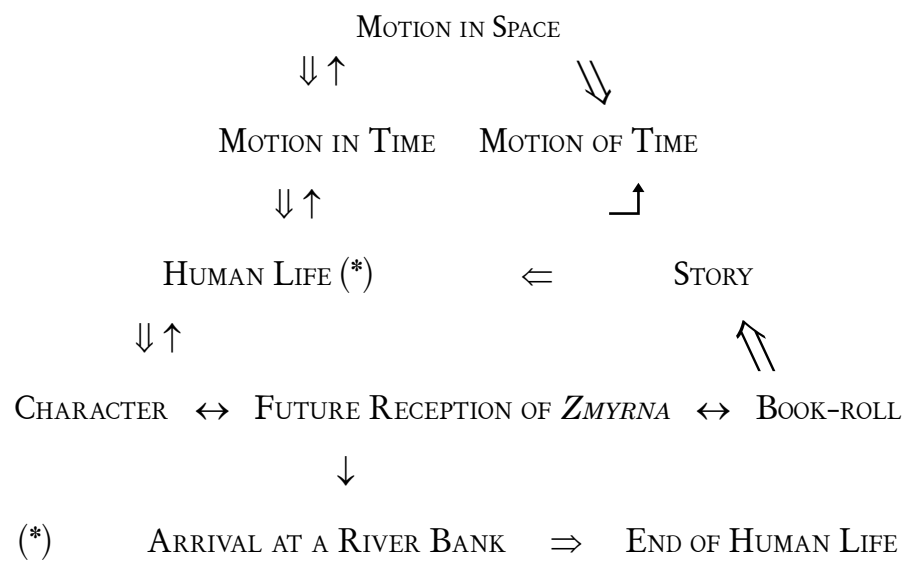

